УдК 316.356.2(47+57)

\title{
СОЦИОЛОГИЯ СЕМЬИ В РОССИИ: МЕТОДОЛОГИЧЕСКИЕ ПРОЕКЦИИ И СОВРЕМЕННЫЕ НАУЧНО-ИССЛЕДОВАТЕЛЬСКИЕ ПРАКТИКИ
}

\author{
Вялых Никита Андреевич, \\ sociology4.1@yandex.ru \\ Институт социологии и регионоведения Южного федерального университета, \\ Россия, 344006, г. Ростов-на-Дону, ул. Пушкинская, 160.
}

Вялых Никита Андреевич, кандидат социологических наук, доцент кафедры теоретической социологии и методологии региональных исследований Института социологии и регионоведения Южного федерального университета.

В статье рассматриваются особенности предметной области фамилистических исследований в современной российской социологии. Цель заключается в переоценке предметных границ и выявлении методологических проблем социологии семьи. Новизна работы выражается в определении внешненаучных и внутринаучных факторов, отличающих методологию социологического познания брачно-семейных отношений от методологии других наук. Статья состоит из двух основных частей. В первой части раскрываются основные методологические подходы к научному изучению брачно-семейной сферы: структурно-функциональный анализ, конфликтологическая парадигма, теории интерпретации человеческого поведения (Феноменология, этнометодология, драматургический подход, символический интеракционизм, теория обмена), институционализм, феминистические концепции. Аргументируется возможность интеграции объективистской и субъективистской методологических проекций для лучшего социологического понимания брачно-семейного поведения в контексте трансформации семьи как социального института. Во второй части статьи анализируются актуальные научно-исследовательские практики в российской социологии семьи. Наиболее разработанными проблемно-предметными полями в отечественной социологии семьи являются: процессы социализации и воспитания в семье; межэтнические браки; типы семей и формы семейного образа жизни; семейно-брачные представления, ценности и установки молодежи; семьи группы риска; роль гендера в брачно-семейных отношениях. Автор приходит к выводу о тенденции преодоления познавательной односторонности различных методологических подходов, равно как и макро- и микросоциологии семьи, в попытке создания всеобъемлющей социологической теории семьи.

Ключевые слова: Социология семьи, методология социологического познания, социальный институт семьи, брачно-семейное поведение, гендерный подход, трансформация семьи, макросоциология семьи, микросоциология семьи.

\section{Введение}

Спектр современных социологических исследований брачно-семейных отношений в России чрезвычайно разнообразен. Социология семьи - одна из самых популярных отраслей социологического знания, давно переросшая статус теории среднего уровня (в мертоновском понимании). Этому феномену есть ряд объяснений. Вопервых, социология семьи зародилась практически одновременно с общей социологией, если говорить о периоде ранней классики, поэтому накопившееся к настоящему моменту количество социологических исследований теоретического и эмпирического характера подсчету не подлежит. Вместе с тем в социально-гуманитарном знании, еще 
до институционализации общей социологии, сложился громадный пласт «предсоциологических» взглядов на семейно-брачную сферу. Здесь речь идет о философских концепциях, религиозных учениях, исторических и этнографических данных. Во-вторых, изобилие научных идей и социологической информации о семье продиктовано чисто человеческим интересом исследователей, особенно женщин, к сфере семейно-брачных отношений. К тому же повышенное внимание к семейно-брачной проблематике в России вызвано освобождением социологии от идеологических догматов советской науки, поскольку многие аспекты семейной повседневности и быта, семейного поведения было просто не принято изучать до начала 90-х гг. В-третьих, институт семьи, несмотря на структурно-векторные противоречия и парадоксы своей трансформации, до сих пор остается одним из самых стабильных социальных институтов наравне с государством, экономикой, религией, образованием, здравоохранением, наукой и культурой. А всевозможные кризисы, аномалии, конфликты, дисфункции, институциональные ловушки только подогревают когнитивный интерес социологов к проблемам семьи и брака. Научные проблемы, в свою очередь, появляются, как правило, не «за окном», а в сознании отдельных ученых и коллективном разуме исследовательских групп. Просто не все социологи готовы в этом честно признаться даже самим себе.

Однако в дальнейшем постараемся избегать каких-либо оценочных суждений, критики, а самое главное - лозунгов, банальностей и штампов в духе «семья - важнейший институт российского общества на современном этапе его трансформации», которые так часто мелькают в современных социологических трудах. Цель данной статьи заключается не в пересказе уже много раз пересказанных теорий, концепций семьи и брака (хотя от этого сложно отойти полностью), а в переоценке методологических традиций социологического познания брачно-семейных отношений. Также в статье предлагается аналитический обзор актуальных направлений социологических исследований в отечественной фамилистике.

\section{Методологические проекции социологического исследования брачно-семейной проблематики}

Методологический плюрализм общей социологии проецируется и на отраслевые социологии. В данном разделе статьи предлагается обзор гносеологического потенциала и ограничений различных теоретико-методологических традиций социологического исследования семьи и брака. Методологическую базу социологии семьи составляют структурно-функциональный анализ, конфликтологическая парадигма, теории интерпретации человеческого поведения (феноменология, этнометодология, драматургический подход, символический интеракционизм, теория обмена), институционализм и феминистические концепции. Это далеко не полный перечень методологических оснований социологии семьи, да и рубрицировать их можно тоже по-разному. Так, по критерию доминирующей познавательной ориентации можно выделить классическую, неклассическую и гибридную (неоклассическую) модели научных исследований семьи [1, с. 26-35]. Часто для обозначения используемой методологической оболочки исследований употребляют термины «метапарадигма» и «стратегия научного познания».

Сам термин «метапарадигма» в социологии полисемантичен, да и классификаций социологических метапарадигм тоже немало. Наиболее известны классификации метапарадигм и парадигм В.А. Ядова, Ж.Т. Тощенко, Г.Е. Зборовского, С.А. Кравченко, Дж. Ритцера. В нашу задачу не входит специальное уточнение всех этих терминов и подсчет метапарадигм (моделей, стратегий), существующих в современной социологической науке, поэтому примем, пусть и с некоторой долей избирательности, уже разра- 
ботанные в отечественной социологии понятия и классификации. Г.Е. Зборовский под метапарадигмой понимает обобщающую теоретическую характеристику ряда близких, родственных парадигм как определенных совокупностей фундаментальных оснований научного знания, исходных концептуальных схем, крупных теорий и их групп, методов и признанных достижений в конкретной науке [2]. Ю.Г. Волков и А.В. Лубский оперируют категорией модели сочииолгического исследования, говоря о том, что это когнитивные аналоги, методологические конструкции идеального типа, концептуально воспроизводящие наиболее типичные черты научно-исследовательских практик в социологии [3, с. 5].

Социология, стремящаяся все типизировать и упорядочить, достаточно быстро отреагировала на многообразие мнений, идей, взглядов методологическим раздвоением на объективистскую и субъективистскую парадигмы, социологический номинализм и социологический реализм, количественную социологию и качественную социологию. Научное противостояние, пусть и очень условное, объективизма и субъективизма в исследовании семейной проблематики постепенно сглаживается. В настоящее время наметилась тенденция преодоления гносеологической односторонности субъективистского и объективистского подходов. Синтетический сплав идей номинализма и реализма Ж.Т. Тощенко называет соииологическим конструктивизмом, в рамках которого «общественное сознание и поведение исследуется в условиях социальной среды» [4]. Методологическая стратегия социологического конструктивизма позволяет установить взаимосвязь между социальной реальностью (семьей в контексте ее институциональных взаимосвязей и процессом ее трансформации как социального института) и индивидуальной реальностью как сферой повседневной жизни «некомпетентных» акторов людей, инкорпорированных в семейные отношения, с их мотивами, ценностями, установками, эмоциями, представлениями и ожиданиями.

Структурно-функцииональный анализ в социологии семьи связан с именами О. Конта, Г. Спенсера, Э. Дюркгейма, П. Сорокина, Б. Малиновского, Т. Парсонса, Р. Мертона. Социологические взгляды на семью каждого из ученых уникальны, но общим для всех концепций данного лагеря является постепенный отказ от историкосравнительного метода в описании эволюции семьи в пользу изучения ее структуры, социальных функций и дисфункций, универсальных типологий, внешних и внутренних связей, взаимодействий с другими институтами, нынешних и будущих состояний, форм солидарности [5]. Отличительной чертой функционализма в социологии является апелляция к стабильности семьи как структурного элемента общества, тесно связанной своими функциями с обществом как целым [6]. Идеальной семьей сторонники функционального подхода, по словам Н.И. Мазаевой, считают эгалитарную, в которой супруги «двигаются прогрессивно шаг за шагом» с разделением общей ответственности за социальные процессы в семье [7].

Однако структурно-функционального подхода с его солидаристским посылом, пусть и признающим дисфункции и кризисные состояния семьи, недостаточно для комплексной социологической оценки факторов брачно-семейных отношений. Методологическим противовесом солидаристской линии структурно-функционального подхода на всех этапах развития социологии была конфликтологическая парадигма, которая, впрочем, внутренней гомогенностью идей, так же как и функциональная парадигма, не отличается. Семья рассматривается здесь как социальное пространство противоречий и антагонизмов. На микроуровне - это конфликты внутри семьи (включая внутриличностные ролевые конфликты), на макроуровне - конфликты между поколениями, социальные конфликты семьи с другими социальными институтами. Основная идея 
конфликтологического подхода в целом, по справедливому мнению Е.М. Черняк, состоит в том, что семья воспроизводит себя через баланс конфликтов, и конфликты - это «обратная, неизбежная сторона интеграции» [6, с. 36].

Социологи связывают семейные конфликты и стрессовые ситуации в семье, как правило, с экономическим давлением, поскольку даже в обеспеченных семьях тема денег не исчезает из конфликтных тематик, во-первых, из-за потенциального перманентного превышения потребностей и желаний членов семьи по отношению к трате денег над реальными ресурсными возможностями, во-вторых, из-за чувства депривации по поводу распределения доступа к имеющимся ресурсам [8].

Группу теорий интерпретации человеческого поведения, характерных для социологии повседневности (феноменология, этнометодология, драматургический подход, символический интеракционизм, теория обмена), можно отнести к неклассической модели научного исследования семьи, в центре внимания которой находятся семья и личность в семье как субъекты деятельности, обладающие специфическими потребностями. Методологические традиции неклассической модели научной рациональности ориентированы на «первичность человека и вторичность общества как продукта взаимодействия между людьми» [1, с. 29]. В «мягких» интерпретативных концепциях исследуются семейное и демографическое поведение [9], семейные интеракции, жизненный мир семьи [10], повседневные практики семейного образа жизни [11], механизмы трансляции ценностей этнической культуры в семье [12]. Именно феноменология, этнометодология, драматургический подход, символический интеракционизм, теория обмена, по мнению А.И. Антонова, составляют методологический корпус микросоциологии семьи [13].

Научные направления социологических исследований, подчеркивающие трансакционные (процессные) перспективы, в которых группы близких людей через их поведение генерируют чувство семейной идентичности с эмоциональными связями, взаимной заботой, опытом истории и будущего, как отмечает О.Н. Бурмыкина, сегодня становятся очень популярными [14, с. 150]. Это отнюдь не означает, что вышеперечисленные области социальной реальности нельзя исследовать с позиции объективизма и «жестких» формализованных методов количественной социологии. В идеале результаты количественных исследований в сфере социологии семьи должны дополняться потенциалом субъективистской парадигмы и драматургией качественной методологии. К примеру, А.В. Верещагина, изучая трансформацию института семьи и демографические процессы в российском обществе в своей докторской диссертации, доказала необходимость и возможность применения нового методологического инструментария, интегрирующего трансформационный подход, неоинституционализм, концепции жизненного цикла семьи и гендера для глубокого анализа демографического поведения семьи [15].

С позиции институциионального подхода семья представляет собой систему «формальных норм и правил, неформальных и индивидуальных ограничений, регулирующих семейное поведение индивидов» [9, с. 89]. Не будет ошибкой признать теории институтов самыми «социологическими» в социологии семьи, ибо социология традиционно имеет дело с паттернами поведения, ролями и статусами. Под институциональным паттерном принято понимать «комплекс причинно-функциональных связей и прежде всего социального плана, детерминирующий значимые константы поведения» [16, с. 29]. М.Д. Херсковиц справедливо отмечает, что для социолога применение понятия паттерна к проблемам, которыми он интересуется, имеет следствием то, что они открываются ему во многом так же, как исследователю физиологии открываются при вскры- 
тии мышцы тела. Понятие паттерна дает способность увидеть социологическую проблему с ясностью прямо-таки удивительной при той отстраненности, которой достигает исследователь [17]. В частности, понятие паттерна позволяет с некоторой степенью обособленности исследовать парадоксы и противоречия трансформации института семьи и брака в современном российском обществе. Т.А. Гурко говорит о новом институциональном подходе в социологии семьи, согласно которому «институциональное поведение не требует сознательного мышления со стороны актора, который полагается на познавательные схемы как рутинную часть жизни» [18, с. 34].

Особое место в методологии социологического изучения семьи занимает феминизм, который эксплицирует «одногендерную» интерпретацию социального мира и основан на идее равноправия полов [13]. Отчасти феминистические теории можно отнести к конфликтологическому направлению, поскольку семья рассматривается как социальное пространство борьбы женщин с патриархальными устоями в интересах достижения равноправия во всех сферах жизни общества, особенно в экономической и политической подсистемах. Феминистические концепции, в отличие от функциональной и институциональной парадигм, смещают смысловой центр фамилистических исследований на «изучение силы женщины, бросающей вызов установкам современности, и социально-психологических характеристик женственности и мужественности» [7, с. 28].

Со временем феминистический подход утратил популярность и трансформировался в гендерный подход, в рамках которого сегодня проводятся не только «женские исследования», как это было «по умолчанию» на ранних этапах зарождения гендерной социологии [19]. Предметом современных гендерных исследований в социологии, как замечает основатель гендерной школы научных исследований в России Г.Г. Силласте, является «социальный статус мужчин и женщин как гендерных общностей и его эволюция под влиянием конкретных условий (исторических, политических, экономических, духовных)» [20, с. 79]. По мнению Г.Г. Силласте, сегодня можно наблюдать обоснованное научное осознание категории гендерных исследований, которые изучают положение не только женщин, но и мужчин в различных сферах общественной жизни. Об этом свидетельствует «фракционализм» гендерных исследований, их конструирование в конкретные направления прикладного научного знания: гендерную социологию, гендерную психологию, гендерную историю, гендерную экономику, гендерную медицину, гендерную педагогику и гендерное право [21, с. 52].

\section{Семья как объект научно-исследовательских практик в современной российской социологии}

Уже традиционной для отечественной фамилистики стала тема брачности и разводимости. В социологических исследованиях по данному профилю уделяется внимание факторам и тенденциям брачного и постбрачного поведения, причинам разводов, социальным нормам формального и неформального плана, которые нормируют поведение людей в сфере брачно-семейных отношений [22-24]. Феномен неблагополучных семей, методы социальной работы и специфика социализации детей в «семьях социального риска» рассматриваются в трудах В.В. Завражнова, Г.М. Зининой, И.Н. Развариной, В.Н. Барсукова, Е.О. Смолевой, Л.Н. Фахрадовой, А.И. Кагармановой, А.В. Верещагиной, В.И. Курбатова, А.В. Попова [25-28]. Дискуссионным в современной социологии семьи остаются вопросы функционального значения и социальных эффектов неполных семей [29-32]. Г.Л. Воронин и А.Л. Янак связывают распространение монородительских семей с результатом актуальных общемировых тенденций и трансформаций в семейной сфере, оценивая практики образования неполных семей как демонстрацию 
«модернизационного потенциала института семьи». Однако исследователи констатируют негативные факторы и последствия монородительства, прежде всего - падение уровня и качества жизни в обществе, снижение потенциала успешности социализации детей [33].

Одним из самых популярных и, наверное, наиболее фундаментальным с социологической точки зрения представляется блок исследований, в которых анализируются специфические для семьи функции социализации и воспитания. Причем авторы фокусируются не только на различных аспектах социализации подрастающего поколения. Интересными представляются работы, в которых изучаются механизмы социализации родителей $[34,35]$, в частности вопросы участия отцов в воспитании детей [36]. И.Ф. Дементьева и З.Т. Голенкова, анализируя многообразные теории семейного воспитания, пришли к выводу о том, что сегодня можно говорить о единой системной концепции воспитания, которая возникла «в пространстве между двух устойчивых социальных доктрин: педагогической теории воспитания и социологической теории семьи и семейных отношений» [37, с. 542]. К социологическим авторы относят теории глобализации, социального капитала, информации, социального неравенства, социальных рисков, разделения власти, гендера, рационального выбора, синергетики, малых групп, массовых коммуникаций.

Социальные представления и установки молодежи носят наиболее динамичный и парадоксальный характер, поэтому в центре современных социологических исследований чаще всего оказывается молодая семья, ее жизненный мир и типичные трудности существования, особенности отношения холостых и незамужних молодых людей к семье и браку [38-40]. Как отмечают В.П. Свечкарев и Я.В. Сердюченко, молодые семьи на начальном витке своего жизненного цикла сталкиваются с комплексом проблем, продуцирующих трудности адаптационного характера, что «определяет в значительной степени случайный, вероятностный характер принимаемых супругами решений и потенциально усиливает риск разрушения их жизненного мира» [41].

Наиболее тесные внутридисциплинарные связи у социологии семьи прослеживаются с гендерной социологией. Гендерная дифференциация представлений об исполнении ролевых предписаний в семье, кризис маскулинного мира как предпосылка перехода к неоматриархальным семьям, современные теории маскулинности и отцовства, благополучие мужчин и женщин с различным брачным статусом - таким видится шорт-лист гендерной проблематики в отечественной социологии семьи. Оригинальной в этом ключе представляется концепщия неоматриархата представителей ростовской социологической школы (А.В. Верещагина, В.В. Ковалев, С.И. Самыгин), доказывающих, что в условиях либерализации и демократизации общества система патриархата стала разрушаться, и основой трансформационного процесса всего общества и его системы становится семья как микроячейка общества. Под влиянием этих обстоятельств обществу потребовался новый тип человека, новый тип общественных отношений, в основе которых лежат ценности свободы, равенства, индивидуализма, независимости, креативности. Вследствие этого «патриархально-авторитарный тип воспитания стал невостребованным, и современное общество возвращается к своим истокам - матриархату как альтернативной системе воспитания и организации семейных отношений» [42]. Конечно, позиция исследователей достаточно дискуссионная, да и эмпирически верифицировать гипотезу об «историческом камбеке» матриархальных устоев не так просто, однако недооценивать смену гендерной картины мира и связанные с ней социальные последствия в развитых странах действительно нельзя. 
Учитывая поликультурность и развитую этносоциальную структуру российского общества, фамилисты активно изучают межэтнические браки, их значение для стабильности и интеграции социума, отношение различных социальных групп к этнически смешанным семьям $[12,43]$. Именно в семье закладывается первичный уровень идентичности личности и именно от внутрисемейных ценностей, традиций, норм зависит самоопределение человека в культурной и духовной сферах жизни общества, его стереотипы по отношению к представителям различных этносов. Ни один проект нациестроительства в современной России не обходится без внимания к этносоциальным процессам в семейно-брачной сфере [44], которая только на микроуровне является приватной. По мнению С.В. Лурье, «российский национальный сценарий формируется как бы на двух уровнях - этнокультурном, где намечается все большее расхождение культур различных народов, и этнопсихологическом, где поддерживает себя общий поведенческий сценарий, одним из выражений которого и является достаточно широкое распространение межэтнической брачности» [43, с. 75]. Т.А. Гурко и В.С. Тарченко на основе данных социологического опроса студентов старших курсов Москвы и Ставрополя в возрасте 20-24 лет ( $=1408,2018$ г.) «прогнозируют повышение гетерогенности браков среди образованного слоя по критерию этнической/религиозной идентичности, гражданства, возраста, уровня образования и дохода» [23, с. 110]. Такая тенденция, по мнению социологов, может привести как к смягчению межэтнической и социальной напряженности в регионах, так и к новым источникам конфликтов в парах и, следовательно, к нестабильности межэтнических браков в обществе.

Подводя итоги обзора современной социологической литературы, посвященной изучению семьи в российском обществе, мы приходим к выводу о том, что наиболее разработанными проблемно-предметными полями являются: процессы социализации и воспитания в семье; межэтнические браки; типы семей и формы семейного стиля жизни; семейно-брачные представления, ценности и установки молодежи; семьи группы риска; роль гендера в брачно-семейных отношениях. По словам Т.А. Гурко, в российской социологии семьи недостаточно исследованы особенности семей различных профессиональных групп, влияние режима работы супругов на семейное благополучие, а также недооценен потенциал феноменологической традиции в изучении семейного жизненного пути, «не верифицировано ныне модное на Западе понятие «амбивалентности» для изучения супружеских и межпоколенческих отношений» $[45,46]$. Е.И. Медведева и С.В. Крошилин на основе системного анализа теоретических работ по проблемам семьи и семейной политики обнаружили отсутствие современных отечественных разработок по тематике самоорганизации в семье и трансформации посемейной структуры [47]. Еще не решенными являются функциональные проблемы семьи, связанные с социокультурными практиками акторов в процессе ожидания ребенка. Поэтому Е.П. Шихова предлагает новую «подотрасль» социологии семьи - пренатальную социологию - междисциплинарную область социологического знания о семье на этапе ожидания ребенка [48]. В рамках данной дисциплины, по замыслу ее автора, для социологов особый интерес представляют изменения ролей внутри семьи, качественные характеристики взаимодействия в семье, типизация межличностных коммуникаций, поведенческие особенности членов семьи, вторичная социализация будущих родителей в период ожидания ребенка в единстве с предсоциализацией индивида [48].

\section{Выводы}

Предметное поле социологических исследований семьи чрезвычайно широко ввиду уникальности самой семьи, сочетающей в себе признаки как малой социальной 
группы, так и социального института. Макросоциология семьи фокусируется на определении роли семьи в социальной структуре общества, исследуя симбиотическую связь между обществом и семьей. Макросоциологи изучают механизмы влияния различных социальных институтов (экономика, политика, образование, религия, здравоохранение и медицина и пр.) на семью, равно как и обратное влияние семьи на архитектонику институциональной матрицы общества. В микросоциологии семьи изучаются жизненный цикл семьи, закономерности ее зарождения, развития и распада, особенности и модели семейного поведения, динамика межличностных отношений в семье [13]. В попытке научной рефлексии дуальности факторов институционального и поведенческого уровней сферы семейно-брачных отношений, социальной структуры семьи и в то же время места семьи в социальной структуре общества и выражается специфика социологического ракурса, отличающего его от других дисциплинарных подходов.

Предметом социологии являются типические, повторяющиеся формы социальных отношений и взаимодействий в семье, типовые структуры и модели брачно-семейных отношений. Конечно, постмодернистская методологическая проекция в социологии предлагает самые неожиданные и эвристические сценарии фамилистических исследований, однако проблемы индивидуально-психических реакций человека внутри семьи социология, как правило, не исследует. Социологи хоть и изучают семью как малую группу, ее жизненный цикл, межпоколенческие отношения, семейное поведение [13], но все равно с перспективой выхода на обобщения макросоциального уровня.

Представляется, что большинство семьеведов склонны скорее к получению эмпирической информации, позволяющей интерпретировать происходящие процессы в брачно-семейной сфере «здесь и сейчас». Подобная исследовательская стратегия, безусловно, способствует приращению научного знания и гарантирует быстрый результат. Но в дальнесрочной перспективе развитие социологии семьи как научной отрасли знания и как учебной дисциплины невозможно без попыток построения новых концепций и объяснительных моделей. Научная конкуренция эмпириков и теоретиков в социологии длится около века, если вести отсчет от институционализации школы эмпирических исследований. Становится все более очевидным, что эмпирики взяли верх в этой необъявленной методологической войне. И надо отдать должное - по справедливости, т. к. социология стала полноценной наукой только к середине XX в., обретя эмпирический и прикладной уровни познания.

Вместе с тем для прогресса социологической науки ученым недостаточно ориентироваться только на внешние запросы общества и пресловутый «социальный заказ». Нужно параллельно проводить ревизию фундаментальных принципов научного познания, имманентных законов развития самой науки, что отражает суть методологической идеологии интернализма. Как раз этого баланса теории и эмпирии, количественной и качественной стратегии исследования, объективизма и субъективизма в российской социологической мысли, включая семейную проблематику, на наш взгляд, не достает. Несмотря на то, что современная социология в России - достаточно демократичная и открытая область знания, многим исследователям, особенно молодым, которые только делают первые шаги в науке, приходится балансировать между мейнстримовыми темами, рискуя в перспективе слиться с общей массой ученых и «выйти в тираж» (читай быть более-менее узнаваемым и цитируемым), и социологическим андеграундом, оставаясь «непризнанными гениями» с отвергнутыми научным сообществом новаторскими концепциями. 


\section{СПИСОК ЛИТЕРАТУРЫ}

1. Лубский А.В. Методология региональных исследований. - М.: Инфра-М, 2019. - 223 с.

2. Зборовский Г.Е. Метапарадигмальная модель теоретической социологии // Социологические исследования. - 2008. - № 4. - С. 3-15.

3. Волков Ю.Г., Лубский А.В. Социология как способ самопознания общества // Социологические исследования. - 2018. - № 7 (411). - С. 3-12.

4. Тощенко Ж.Т. Парадигмы, структуры и уровни социологического анализа // Социологические исследования. - 2007. - № 9. - С. 5-16.

5. Голод С.И. Семья и брак: историко-социологический анализ. - СПб.: ТОО ТК «Петрополис», 1998. $272 \mathrm{c}$.

6. Черняк Е.М. Социология семьи. - М.: Дашков и Ко, 2004. - 238 с.

7. Мазаева Н.И. Семейные отношения в контексте социальных трансформаций // Общество: философия, история, культура. - 2019. - № 2 (58). - С. 27-30.

8. Попова П.А. Как объяснить финансовый конфликт в семье? Обзор экономических, психологических и социологических концепций // Экономическая социология. - 2017. - Т. 18. - № 2. - С. 112-137.

9. Верещагина А.В. Институциональные изменения в семейной сфере и демографические перспективы России: методологическая матрица исследования // Гуманитарий Юга России. - 2012. - № 4. - С. $82-93$.

10. Сердюченко Я.В. Жизненный мир молодой семьи: методология социологического исследования // Социально-гуманитарные знания. - 2017. - № 7. - С. 234-243.

11. Риббенс Маккарти Дж., Эдвардс Р. Исследования семьи: основные понятия - М.: ИД Высшей школы экономики, 2018. - 343 с.

12. Панфилова Ю.С. Семья как институт сохранения и трансляции ценностей традиционной этнической культуры // Социально-гуманитарные знания. - 2017. - № 11. - С. 324-331.

13. Антонов А.И. Микросоциология семьи (методология исследования структур и процессов). - M.: Nota Bene, 1998. - $360 \mathrm{c}$.

14. Бурмыкина О.Н. Социологические концептуализации семьи: анализ зарубежного и отечественного опыта // Петербургская социология сегодня. - 2010. - Т. 1. - С. 142-151.

15. Верещагина А.В. Трансформация института семьи и демографические процессы в российском обществе: дис. ... д-ра социол. наук. - Ростов-на-Дону, 2009. - 419 с.

16. Кремнева Е.В. Институциональный паттерн конкурентоспособности и развития российской экономики // Вестник Саратовского государственного социально-экономического университета. - 2011. № 4. - С. 29-32.

17. Херсковиц М.Д. Социальный паттерн: методологическое исследование // Личность. Культура. Общество. - 2011. - Т. 13. - № 1. - С. 34-48.

18. Гурко Т.А. Теоретические подходы к изучению трансформации института семьи // Социологический журнал. - 2020. - № 1. - С. 31-54.

19. Силласте Г.Г. Гендерная социология: от идеи и дискуссий к научной школе // Гуманитарий Юга России. - 2016. - Т. 19. - № 3. - С. 15-30.

20. Силласте Г.Г. Гендерная социология: состояние, противоречия, перспективы // Социологические исследования. - 2004. - № 9. - С. 77-84.

21. Силласте Г.Г. От решения женского вопроса к новому гендерному порядку: движение в модусах социального времени // Гуманитарий Юга России. - 2017. - Т. 6. - № 5. - С. 48-62.

22. Синельников А.Б., Дорохина О.В. Брак и развод в России с точки зрения формальных и неформальных социальных норм // Известия Саратовского университета. Новая серия. Серия «Социология. Политология». - 2015. - Т. 15. - № 3. - С. 21-28.

23. Гурко Т.А., Тарченко В.С. Динамика брачных установок и планов студентов // Социологические исследования. - 2019. - № 7. - С. 102-113.

24. Гурко Т.А. Благополучие мужчин и женщин различного брачного статуса: Россия в международном контексте // Социологический журнал. - 2018. - Т. 24. - № 1. - С. 73-94.

25. Завражнов В.В., Зинина Г.М. Возможности социальной работы с детьми из неблагополучных семей // Научные исследования: от теории к практике. - 2015. - № 5 (6). - С. 192-193.

26. Основные направления работы с детьми и их семьями, находящимися в трудной жизненной ситуации и социально опасном положении / И.Н. Разварина, В.Н. Барсуков, Е.О. Смолева, Л.Н. Фахрадова // Проблемы развития территории. - 2016. - № 3 (83). - С. 81-99.

27. Кагарманова А.И. Проблема формирования семейных ценностей у детей из неблагополучных семей // Актуальные направления научных исследований: от теории к практике. - 2015. - № 4 (6). - С. 68-71.

28. Верещагина А.В., Курбатов В.И., Попов А.В. Неблагополучное детство в России: парадоксы управленческой реальности в сфере семейных отношений // Вестник Южно-Российского государственного 
технического университета (Новочеркасского политехнического института). Серия «Социальноэкономические науки». - 2018. - № 1. - С. 100-106.

29. Кантемирова Г.А. Неполная семья как феномен большого города // Социология города. - 2015. № 2. - С. 32-39.

30. Чурилова Е.В. Состав и благосостояние неполных семей в России // Социологические исследования. - 2015. - № 3 (371). - С. 78-81.

31. Курагина Г.С. Особенности социализации детей из неполных семей // Академия профессионального образования. - 2015. - № 7 (49). - С. 47-52.

32. Салпагаров А.А. Организация социально-педагогической помощи неполной семье в воспитании детей // Science Time. - 2015. - № 6 (18). - С. 441-445.

33. Воронин Г.Л., Янак А.Л. Монородительские семьи: их типы и социальный портрет одинокого родителя // Женщина в российском обществе. - 2018. - № 1 (86). - С. 53-66.

34. Верещагина А.В., Ковалев В.В., Самыгин С.И. Роль экономического фактора в трансформации неполной семьи (на примере семей одиноких матерей) // Историческая и социально-образовательная мысль. - 2017. - Т. 9. - № 4-2. - С. 133-140.

35. Лотова И.П. Социология родительства как отдельная предметная область социологии семьи // Статистика и Экономика. - 2016. - № 2. - С. 2-5.

36. Шевченко И.О. Ситуация после развода: отцы и дети // Социологические исследования. - 2015. № 3 (371). - С. 70-77.

37. Дементьева И.Ф., Голенкова 3.Т. Теория семейного воспитания в общетеоретическом контексте социальных наук // Вестник Российского университета дружбы народов. Серия «Социология». 2018. - Т. 18. - № 3. - С. 542-554.

38. Шахбанова М.М., Верещагина А.В., Самыгин С.И. Жизненный мир молодой семьи и проблемы его формирования в условиях парадоксальной российской реальности // Гуманитарные, социальноэкономические и общественные науки. - 2018. - № 9. - С. 59-66.

39. Ковалев В.В., Верещагина А.В., Самыгин С.И. Проблемы и риски молодой семьи первого года жизни с позиций ее типологической характеристики (нуклеарные и многопоколенные семьи) // Государственное и муниципальное управление. Ученые записки СКАГС. - 2016. - № 4. - С. 186-191.

40. Раннее материнство как многоаспектный и многофакторный феномен / В.В. Орлова, Э.И. Мещерякова, А.В. Ларионова, Е.А. Антипова // Векторы благополучия: экономика и социум. - 2020. - № 1. C. $1-11$.

41. Свечкарев В.П., Сердюченко Я.В. Адаптивные модели преодоления рисков жизненного мира молодой семьи // Инженерный вестник Дона. - 2018. - № 3 (50). URL: http://www.ivdon.ru/ru/magazine/archive/n3y2018/5110 (дата обращения 03.06.2020).

42. Верещагина А.В., Ковалев В.В., Самыгин С.И. Неоматриархат в условиях кризиса патриархальной семьи: становление новой гендерной картины мира // Гуманитарные, социально-экономические и общественные науки. - 2018. - № 3. - С. 13-18.

43. Лурье С.В. Отношение к межэтническим бракам как симптом формирования российской идентичности // Петербургская социология сегодня. - 2019. - Вып. 11. - С. 68-80.

44. Национальная политика в России: возможность имплементации зарубежного опыта / Ю.Г. Волков, А.В. Бедрик, В.П. Войтенко и др. - М.: Социально-гуманитарные знания, 2016. - 318 с.

45. Гурко Т.А. Становление социологии семьи в России // Социологические исследования. - 2018. № 6. - C. 40-52.

46. Гурко Т.А. Понятие амбивалентности в изучении семейных отношений // Социологические исследования. - 2020. - № 2. - С. 63-73.

47. Медведева Е.И., Крошилин С.В. Российская семья и экономика страны // Социальное пространство. -2017 . - № 5 (12). - С. 1-16.

48. Шихова Е.П. Новые междисциплинарные акценты в социологии: семья на этапе ожидании ребенка // Вестник Тихоокеанского государственного университета. - 2015. - № 1 (36). - С. 287-294.

Поступила 05.06.2020 2. 
UDC 316.356.2(47+57)

\title{
SOCIOLOGY OF THE FAMILY IN RUSSIA: METHODOLOGICAL PROJECTIONS AND ACTUAL RESEARCH PRACTICES
}

\author{
Nikita A. Vyalykh, \\ sociology4.1@yandex.ru \\ Southern Federal University, \\ 160, Pushkinsky avenue, Rostov-on-Don, 344006, Russia.
}

Nikita A. Vyalykh, Cand. Sc., associate professor, Southern Federal University.

The article deals with the specific features of the family studies subject area in Russian sociology today. The aim of the article is a revision of subject boundaries and methodological problems of the family sociology. The novelty of the work is in identifying the externalist and internalist factors, differentiating the sociological research methodology of marriage and family relations from the one in other sciences. The paper is into two main parts. In the first part the basic methodological approaches of scientific research in marriage and family sphere are revealed; there are structural and functional analysis, conflictological paradigm, theories of human behavior interpretation (phenomenology, ethnomethodology, dramaturgical approach, symbolic interactionism, exchange theory), institutionalism, feminist concepts. The author argues the possibility of integrating objectivist and subjectivist methodological projections for better sociological understanding of the marriage and family behavior in the context of transformation of the family as a social institute. The second part deals with actual research practices of family studies in Russian sociology. It is showed that the most developed subject fields of family studies in Russian sociology are: socialization and upbringing in the family; interethnic marriages; types of families and forms of family life style; family and marriage ideas, values and attitudes of youth; families of risk groups; the role of gender in marriage and family relations. The author comes to the conclusion about the tendency to overcome the cognitive one-sidedness of various methodological approaches, as well as macro- and microsociology of the family, in an attempt to create a comprehensive sociological family theory.

Key words: Sociology of the family, methodology of sociological knowledge, social institute of the family, marriage and family behavior, gender approach, family transformation, macrosociology of the family, microsociology of the family.

\section{REFERENCES}

1. Lubsky A.V. Metodologiya regionalnykh issledovaniy [Regional study's methodology]. Moscow, Infra-M Publ., 2019. 223 p.

2. Zborovskiy G.E. Metaparadigmalnaya model teoreticheskoy sotsiologii [Metaparadigmal model of theoretical sociology]. Sotsiologicheskie issledovaniya, 2008, no. 4, pp. 3-15.

3. Volkov Yu.G., Lubsky A.V. Sotsiologiya kak sposob samopoznaniya obshchestva [Sociology as a way of self-knowledge of society]. Sotsiologicheskie issledovaniya, 2018, no. 7 (411), pp. 3-12.

4. Toshchenko Zh.T. Paradigmy, struktury i urovni sotsiologicheskogo analiza [Paradigms, structures and levels of sociological analysis]. Sotsiologicheskie issledovaniya, 2007, no. 9, pp. 5-16.

5. Golod S.I. Semya i brak: istoriko-sotsiologicheskiy analiz [Family and marriage: history-sociological analysis]. St. Petersburg, Petropolis Publ., 1998. 272 p.

6. Chernyak E.M. Sotsiologiya semi [Sociology of the family]. Moscow, Dashkov and Ko Publ., 2004. 238 p.

7. Mazaeva N.I. Semeynye otnosheniya v kontekste sotsialnykh transformatsiy [Family relations in the context of social transformations]. Obshchestvo: filosofiya, istoriya, kultura, 2019, no. 2 (58), pp. 27-30.

8. Popova P.A. Kak obyasnit finansovy konflikt v seme? Obzor ekonomicheskikh, psikhologicheskikh i sotsiologicheskikh kontseptsiy [How to explain the financial conflict in the family? Overview of economic, psychological, and sociological concepts]. Ekonomicheskaya sotsiologiya, 2017, vol. 18, no. 2, pp. 112-137. 
9. Vereshchagina A.V. Institutsionalnye izmeneniya v semeynoy sfere i demograficheskie perspektivy Rossii: metodologicheskaya matritsa issledovaniya [Institutional changes in the family sphere and demographic prospects of Russia: methodological matrix of the research]. Gumanitariy Yuga Rossii, 2012, no. 4, pp. 82-93.

10. Serdyuchenko Ya.V. Zhiznenny mir molodoy semi: metodologiya sotsiologicheskogo issledovaniya [The life world of a young family: methodology of sociological research]. Sotsialno-gumanitarnye znaniya, 2017, no. 7, pp. 234-243.

11. Ribbens McCarthy J., Edwards R. Issledovaniya semi: osnovnye ponyatiya [Key concepts of family studies]. Eds. I.N. Tartakovskaya, E.Yu. Rozhdestvenskaya. Moscow, Higher school of Economics Publ., 2018. 343 p.

12. Panfilova Yu.S. Semya kak institut sokhraneniya i translyatsii tsennostey traditsionnoy etnicheskoy kultury [The family as an institution for preserving and transmitting the values of traditional ethnic culture]. Sotsialno-gumanitarnye znaniya, 2017, no. 11, pp. 324-331.

13. Antonov A.I. Mikrosotsiologiya semi (metodologiya issledovaniya struktur i protsessov) [Microsociology of the family (methodology of research of structures and processes)]. Moscow, Nota Bene Publ., 1998. 360 p.

14. Burmykina O.N. Sotsiologicheskie kontseptualizatsii semi: analiz zarubezhnogo i otechestvennogo opyta [Sociological conceptualizations of the family: analysis of foreign and domestic experience]. Peterburgskaya sotsiologiya segodnya, 2010, no. 1, pp. 142-151.

15. Vereshchagina A.V. Transformatsiya instituta semi i demograficheskie protsessy $v$ rossiyskom obshchestve. Dis. Dokt. nauk [Transformation of the family institution and demographic processes in Russian society. Dr. Diss.]. Rostov-on-Don, 2009. 419 p.

16. Kremneva E.V. Institutsionalny pattern konkurentosposobnosti i razvitiya rossiyskoy ekonomiki [Institutional pattern of competitiveness and development of the Russian economy]. Vestnik Saratovskogo gosudarstvennogo sotsialno-ekonomicheskogo universiteta, 2011, no. 4, pp. 29-32.

17. Herskovits M.D. Sotsialny pattern: metodologicheskoye issledovanie [Social pattern: a methodological study]. Lichnost. Kultura. Obshchestvo, 2011, vol. 13, no. 1, pp. 34-48.

18. Gurko T.A. Teoreticheskie podkhody k izucheniyu transformatsii instituta semi [Theoretical approaches to studying the transformation of the family institution]. Sotsiologicheskiy zhurnal, 2020, no. 1, pp. 31-54.

19. Sillaste G.G. Gendernaya sotsiologiya: ot idei i diskussiy k nauchnoy shkole [Gender sociology: from idea and discussion to scientific school]. Gumanitariy Yuga Rossii, 2016, vol. 19, no. 3, pp. 15-30.

20. Sillaste G.G. Gendernaya sotsiologiya: sostoyanie, protivorechiya, perspektivy [Gender sociology: state, contradictions, perspectives]. Sotsiologicheskie issledovaniya, 2004, no. 9, pp. 77-84.

21. Sillaste G.G. Ot resheniya zhenskogo voprosa k novomu gendernomu poryadku: dvizhenie $\mathrm{v}$ modusakh sotsialnogo vremeni [From the solution of the women's question to the new gender order: movement in the modes of social time]. Gumanitariy Yuga Rossii, 2017, vol. 6, no. 5, pp. 48-62.

22. Sinelnikov A.B., Dorokhina O.V. Brak i razvod v Rossii s tochki zreniya formalnykh i neformalnykh sotsialnykh norm [Marriage and divorce in Russia in terms of formal and informal social norms]. Izvestiya Saratovskogo universiteta. Novaya seriya. Seriya «Sotsiologiya. Politologiya», 2015, vol. 15, no. 3, pp. 2128.

23. Gurko T.A., Tarchenko V.S. Dinamika brachnykh ustanovok i planov studentov [Dynamics of students' marital attitudes and plans]. Sotsiologicheskie issledovaniya, 2019, no. 7, pp. 102-113.

24. Gurko T.A. Blagopoluchie muzhchin i zhenshchin razlichnogo brachnogo statusa: Rossiya v mezhdunarodnom kontekste [Well-being of men and women of different marital status: Russia in the international context]. Sotsiologicheskiy zhurnal, 2018, vol. 24, no. 1, pp. 73-94.

25. Zavrazhnov V.V., Zinina G.M. Vozmozhnosti sotsialnoy raboty s detymi iz neblagopoluchnykh semey [Opportunities for social work with children from disadvantaged families]. Nauchnye issledovaniya: ot teorii $k$ praktike, 2015, no. 5 (6), pp. 192-193.

26. Razvarina I.N., Barsukov V.N., Smoleva E.O., Fakhradova L.N. Osnovnye napravleniya raboty s detmi i ikh semyami, nakhodyashchimisya $\mathrm{v}$ trudnoy zhiznennoy situatsii i sotsialno opasnom polozhenii [Main directions of work with children and their families in difficult life situations and socially dangerous situations]. Problemy razvitiya territorii, 2016, no. 3 (83), pp. 81-99.

27. Kagarmanova A.I. Problema formirovaniya semeynykh tsennostey u detey iz neblagopoluchnykh semey [The problem of formation of family values in children from disadvantaged families]. Aktualnye napravleniya nauchnykh issledovaniy: ot teorii k praktike, 2015, no. 4 (6), pp. 68-71.

28. Vereshchagina A.V., Kurbatov V.I., Popov A.V. Neblagopoluchnoe detstvo v Rossii: paradoksy upravlencheskoy realnosti $\mathrm{v}$ sfere semeynykh otnosheniy [Dysfunctional childhood in Russia: paradoxes of managerial reality in the sphere of family relations]. Vestnik Yuzhno-Rossiyskogo gosudarstvennogo tekhnicheskogo universiteta (Novocherkasskogo politekhnicheskogo instituta). Seriya «Sotsialnoekonomicheskie nauki», 2018, no. 1, pp. 100-106. 
29. Kantemirova G.A. Nepolnaya semya kak fenomen bolshogo goroda [Incomplete family as a phenomenon of the big city]. Sotsiologiya goroda, 2015, no. 2, pp. 32-39.

30. Churilova E.V. Sostav i blagosostoyanie nepolnykh semey v Rossii [Composition and welfare of singleparent families in Russia]. Sotsiologicheskie issledovaniya, 2015, no. 3 (371), pp. 78-81.

31. Kuragina G.S. Osobennosti sotsializatsii detey iz nepolnykh semey [Features of socialization of children from single-parent families]. Akademiya professionalnogo obrazovaniya, 2015, no. 7 (49), pp. 47-52.

32. Salpagarov A.A. Organizatsiya sotsialno-pedagogicheskoy pomoshchi nepolnoy seme v vospitanii detey [Organization of social and pedagogical assistance to single-parent families in raising children]. Science Time, 2015, no. 6 (18), pp. 441-445.

33. Voronin G.L., Yanak A.L. Monoroditelskiye semi: ikh tipy i sotsialny portret odinokogo roditelya [Singleparent families: their types and social portrait of a single parent]. Zhenshchina $v$ rossiyskom obshchestve, 2018, no. 1 (86), pp. 53-66.

34. Vereshchagina A.V., Kovalev V.V., Samygin S.I. Rol ekonomicheskogo faktora v transformatsii nepolnoy semi (na primere semey odinokikh materey) [The role of economic factors in the transformation of singleparent families (on the example of single-mother families)]. Istoricheskaya $i$ sotsialno-obrazovatelnaya mysl, 2017, vol. 9, no. 4-2, pp. 133-140.

35. Lotova I.P. Sotsiologiya roditelstva kak otdelnaya predmetnaya oblast sotsiologii semi [Sociology of parenthood as a separate subject area of family sociology]. Statistika i Ekonomika, 2016, no. 2, pp. 2-5.

36. Shevchenko I.O. Situatsiya posle razvoda: ottsy i deti [Situation after divorce: fathers and children]. Sotsiologicheskie issledovaniya, 2015, no. 3 (371), pp. 70-77.

37. Dementeva I.F., Golenkova Z.T. Teoriya semeynogo vospitaniya v obshcheteoreticheskom kontekste sotsialnykh nauk [Theory of family education in the general theoretical context of social sciences]. Vestnik Rossiyskogo universiteta druzhby narodov. Seriya «Sotsiologiya», 2018, vol. 18, no. 3, pp. 542-554.

38. Shakhbanova M.M., Vereshchagina A.V., Samygin S.I. Zhiznenny mir molodoy semi i problemy ego formirovaniya $\mathrm{v}$ usloviyakh paradoksalnoy rossiyskoy realnosti [The life-world of a young family and the problems of its formation in paradoxical conditions of Russian reality]. Gumanitarnye, sotsialnoekonomicheskie i obshchestvennye nauki, 2018, no. 9, pp. 59-66.

39. Kovalev V.V., Vereshchagina A.V., Samygin S.I. Problemy i riski molodoy semi pervogo goda zhizni s pozitsiy ee tipologicheskoy kharakteristiki (nuklearnye i mnogopokolennye semi) [Problems and risks of a young family of the first year of life in terms of its typological characteristics (nuclear and multigenerational families)]. Gosudarstvennoe i munitsipalnoe upravlenie. Uchenye zapiski SKAGS, 2016, no. 4, pp. 186-191.

40. Orlova V.V., Meshcheryakova E.I., Larionova A.V., Antipova E.A. Early motherhood as a multi-aspect and multifactor phenomenon. Journal of Wellbeing Technologies, 2020, no. 1, pp. 1-11. In Rus.

41. Svechkarev V.P., Serdyuchenko Ya.V. Adaptivnye modeli preodoleniya riskov zhiznennogo mira molodoy semi [Adaptive models for overcoming the risks of a young family's life world]. Inzhenerny vestnik Dona, 2018, no. 3 (50). In Rus. Available at: http://www.ivdon.ru/ru/magazine/archive/n3y2018/5110 (accessed 3 June 2020).

42. Vereshchagina A.V., Kovalev V.V., Samygin S.I. Neomatriarkhat v usloviyakh krizisa patriarkhalnoy semi: stanovlenie novoy gendernoy kartiny mira [Neo-patriarchy in the context of the patriarchal family crisis: the formation of a new gender picture of the world]. Gumanitarnye, sotsialno-ekonomicheskie i obshchestvennye nauki, 2018, no. 3, pp. 13-18.

43. Lurye S.V. Otnoshenie k mezhetnicheskim brakam kak simptom formirovaniya rossiyskoy identichnosti [Attitude to interethnic marriages as a symptom of the formation of Russian identity]. Peterburgskaya sotsiologiya segodnya, 2019, no. 11, pp. 68-80.

44. Natsionalnaya politika $v$ Rossii: vozmozhnost implementatsii zarubezhnogo opyta [National policy in Russia: the possibility of implementing foreign experience]. Ed. by Yu.G. Volkov. Moscow, Social and humanitarian knowledge Publ., 2016. 318 p.

45. Gurko T.A. Stanovlenie sotsiologii semi v Rossii [Formation of the family sociology in Russia]. Sotsiologicheskie issledovaniya, 2018, no. 6, pp. 40-52.

46. Gurko T.A. Ponyatie ambivalentnosti v izuchenii semeynykh otnosheniy [The concept of ambivalence in the study of family relations]. Sotsiologicheskie issledovaniya, 2020, no. 2, pp. 63-73.

47. Medvedeva E.I., Kroshilin S.V. Rossiyskaya semya i ekonomika strany [Russian family and national economy]. Sotsialnoe prostranstvo, 2017, no. 5 (12), pp. 1-16.

48. Shikhova E.P. Novye mezhdistsiplinarnye aktsenty v sotsiologii: semya na etape ozhidanii rebenka [New interdisciplinary accents in sociology: the family at the stage of waiting for a child]. Vestnik Tikhookeanskogo gosudarstvennogo universiteta, 2015, no. 1 (36), pp. 287-294.

Received: 5 June 2020. 